\title{
Prevalence and sociodemographic risk factors related to household food security in Aboriginal peoples in Canada
}

\author{
Noreen D Willows ${ }^{1, *}$, Paul Veugelers ${ }^{2}$, Kim Raine ${ }^{2}$ and Stefan Kuhle ${ }^{2}$ \\ ${ }^{1} 410 \mathrm{Ag} /$ For Building, Alberta Institute of Human Nutrition, Department of Agricultural, Food and Nutritional \\ Sciences, University of Alberta, Edmonton, Canada, T6G 2P5: ${ }^{2}$ School of Public Health, University of Alberta, \\ Edmonton, Canada
}

Submitted 16 June 2008: Accepted 5 November 2008: First published online 24 December 2008

\begin{abstract}
Objective: Canada's Aboriginal population is vulnerable to food insecurity and increasingly lives off-reserve. The Canadian Community Health Survey, Cycle 2.2 Nutrition, was used to compare the prevalence and sociodemographic correlates of food insecurity between non-Aboriginal and off-reserve Aboriginal households. Design: Food insecurity status was based on Health Canada's revised interpretation of responses to the US Household Food Security Survey Module. Logistic regression was used to assess if Aboriginal households were at higher risk for food insecurity than non-Aboriginal households, adjusting for household sociodemographic factors. Setting: Canada.

Subjects: Households ( $n$ 35,107), 1528 Aboriginal and 33579 non-Aboriginal.

Results: Thirty-three per cent of Aboriginal households were food insecure as compared with $9 \%$ of non-Aboriginal households (univariate OR 5·2, $95 \%$ CI $4 \cdot 2$, 6.3). Whereas $14 \%$ of Aboriginal households had severe food insecurity, $3 \%$ of non-Aboriginal households did. The prevalence of sociodemographic risk factors for household food insecurity was higher for Aboriginal households. Aboriginal households were more likely to have three or more children (14\%v. 5\%), be lone-parent households ( $21 \% v .5 \%)$, not have home ownership (52\%v. 31\%), have educational attainment of secondary school or less (43\% v. 26\%), have income from sources other than wages or salaries (38\%v. 29\%), and be in the lowest income adequacy category (33\% v. 12\%). Adjusted for these sociodemographic factors, Aboriginal households retained a higher risk for food insecurity than non-Aboriginal households (OR 2·6, $95 \%$ CI $2 \cdot 1,3 \cdot 2$ ).

Conclusions: Off-reserve Aboriginal households in Canada merit special attention for income security and poverty alleviation initiatives.
\end{abstract}

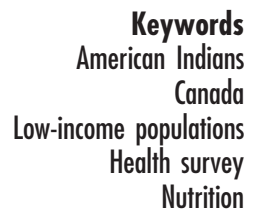

Nutrition
In a wealthy country such as Canada elevated rates of poverty persist among economically vulnerable groups, including Aboriginal (First Nations, Métis, Inuit) $†$ groups ${ }^{(1)}$. Food insecurity, the limited or uncertain availability of nutritionally adequate and safe foods, or the limited or uncertain ability to acquire acceptable foods in socially acceptable ways ${ }^{(2)}$, is widespread in Aboriginal households in Canada ${ }^{(3-7)}$. High levels of poverty, multi-child households, low levels of education achievement and labour force participation, reliance on social assistance and welfare, and female lone-parent families are associated with food insecurity in Aboriginal households ${ }^{(3-8)}$. Canada's Aboriginal population has surpassed the one million mark, is experiencing upward growth, and $54 \%$ of enumerated Aboriginals

$\dagger$ In Canada, First Nations is the preferred term for American Indians. Inuit traditionally inhabited Arctic Canada. Métis have mixed First Nations and European ancestry. live off-reserve $\ddagger^{(9)}$. The off-reserve Aboriginal population has less often been included in health and nutrition surveys than the on-reserve population, in part because the federal government historically took the position that its specific responsibilities for Aboriginal Peoples were limited to Status Indians living on-reserve and Inuit ${ }^{(10)}$. Aboriginals aged 19-50 years living off-reserve were intentionally over-sampled in the Canadian Community Health Survey, Cycle 2.2 Nutrition (CCHS 2.2), which allowed for separate analysis of household food insecurity in this subpopulation ${ }^{(11,12)}$.

The CCHS 2.2 was a cross-sectional survey of Canadians households. Excluded from the survey were persons living on Indian reserves or Crown lands, persons living in institutions, full-time members of the Canadian Forces and residents of some remote regions ${ }^{(11,12)}$. Treasury Board

\$ A reserve is a tract of Crown land (not privately owned) set aside for the use and benefit of an Indian band (community). 
funding did not provide for data collection in the Northwest Territories, Yukon Territory or Nunavut. However, the target population covered by the survey represents approximately $98 \%$ of the population of the ten provinces and is thus considered a national survey ${ }^{(13)}$. The CCHS 2.2 is the only Canada-wide survey to include a multipleindicator measure to derive household food security status using the US Household Food Security Survey Module (HFSSM) ${ }^{(12)}$, which is an internationally recognized 18-question measure of food insecurity resulting from financial resource constraint over the previous 12 months, ranging in severity from worrying about running out of food to children not eating for a whole day. Each question addresses either an issue pertaining to a lack of money or an inability to afford food as the reason for the condition or behaviour ${ }^{(14)}$. Given the array of sociodemographic variables that were collected, the intentional over-sampling of the off-reserve Aboriginal population and the use of the HFSSM to measure food insecurity, the CCHS 2.2 provided an important opportunity to better understand the household-level factors associated with the food security situation of Aboriginal households ${ }^{(12)}$.

We report herein the prevalence of food insecurity for Aboriginal and non-Aboriginal households included in the CCHS 2.2 using a method developed by Health Canada to interpret responses to the $\operatorname{HFSSM}^{(12)}$. The sociodemographic risk factors for food insecurity of Aboriginal and non-Aboriginal households were compared. It was intended that the results could inform about the need for income security strategies and poverty alleviation initiatives for the off-reserve Aboriginal population, in addition to providing a baseline measurement of household food insecurity prevalence to be monitored using the HFSSM in subsequent Canadian Community Health Surveys ${ }^{(12)}$.

\section{Methods}

\section{Survey design and composition}

A complex multistage sampling strategy was used to select participating households and respondents in the CCHS 2.2. A single member of 35107 Canadian households was surveyed between January 2004 and January 2005, of whom 1528 respondents were identified as Aboriginal (59·1\% North American Indian, 37·0\% Métis and $3 \cdot 1 \%$ Inuit; does not add up to $100 \%$ due to rounding). Of Aboriginal respondents, 405 had mixed Aboriginal and non-Aboriginal origin and 1123 had sole Aboriginal identity (i.e. no other cultural/racial group chosen). The overall survey response rate was $76 \cdot 5 \%$. Detailed descriptions of the CCHS 2.2 design, sample and interview procedures are available elsewhere ${ }^{(11,12)}$.

\section{Data access}

Research was conducted under the Research Data Centre (RDC) Program which provided researchers access, in a secure university setting, to the CCHS 2.2 Master File that included data collected from every respondent ${ }^{(15)}$.

\section{Variables}

Household food insecurity status was the outcome variable. Food security status was based on a revised interpretation of the responses to the HFSSM developed by Health Canada's Office of Nutrition Policy and Promotion in consultation with leading experts in nutrition and food security ${ }^{(12)}$. Two levels of food insecurity were defined. Adults and/or children in households with moderate food insecurity reported multiple indicators of problems of food access such as inadequacy in household food supplies or adjustments to the quality of food consumed. In addition to these indicators, households with severe food insecurity also reported disrupted eating patterns and reduced food intake among adults and/or children ${ }^{(12)}$. Due to small numbers, child food insecurity was not considered separately from adult food insecurity. Household food security status information was missing for $<1 \%$ of respondents.

Respondents with sole or mixed Aboriginal identity were considered Aboriginal. All other respondents were considered non-Aboriginal. On the basis of respondent identity, households were categorized as Aboriginal or non-Aboriginal. Information on ethnic status was missing for $<1 \%$ of respondents.

Household-level sociodemographic variables collected by questionnaire were used as covariates in regression analysis (percentage of missing values in parentheses): highest level of education achieved by any member of the household (2.0\%), home ownership ( $<1 \cdot 0 \%)$, household income adequacy based on the number of people in the household and total household income from all sources in the 12 months before the interview (10.0\%), main source of household income $(3 \cdot 0 \%)$. Due to small numbers of observations and the risk of disclosure, the categories for almost all variables had to be more aggregated than the derived variables in the CCHS 2.2. Information on original survey variables is reported elsewhere ${ }^{(16)}$.

\section{Statistical analysis and data bandling}

Prevalence estimates were derived for total household food insecurity and for each of moderate and severe household food insecurity. As not all people in food-insecure households are necessarily food insecure, it was not possible to estimate the individual number of Canadians experiencing food insecurity ${ }^{(12)}$. All estimates were calculated using sampling weights provided by Statistics Canada to account for design effect and non-response bias. Household weights were used to estimate the number of households experiencing food insecurity. Owing to the small number of respondents, rounding of the prevalence estimates was required so as to avoid disclosure ${ }^{(16)}$.

Associations between household overall food insecurity status (moderate and severe food insecurity combined) 
and sociodemographic factors were examined using univariate and multiple logistic regression models. To assess potential differences in the associations of sociodemographic factors with household food insecurity, analyses were initially stratified by Aboriginal and nonAboriginal household status. Univariate odds ratios for household food insecurity for each sociodemographic variable were calculated, as were odds ratios adjusted for all sociodemographic variables. Hosmer and Lemeshow's purposeful selection procedure was used to build the multiple regression model ${ }^{(17)}$. Standard errors were estimated using a bootstrapping procedure ${ }^{(18,19)}$. According to Statistics Canada's policy, data with a moderate CV $(16 \cdot 5-33 \cdot 3 \%)$ were interpreted with caution and data with a $\mathrm{CV}>33 \cdot 3 \%$ or a respondent count of $<30$ were suppressed due to extreme sampling variability ${ }^{(16)}$. The STATA statistical software package version 9 (Stata Corp., College Station, TX, USA) was used to perform the statistical analyses.

Ethics approval for the study was obtained from the Human Research Ethics Board of the Faculty of Agriculture, Forestry and Home Economics, University of Alberta.

\section{Results}

There were an estimated 12000000 non-Aboriginal and 196000 off-reserve Aboriginal households in Canada in 2004. Overall, 33\% of Aboriginal households surveyed were food insecure as compared with $9 \%$ of non-Aboriginal households. The univariate odds ratio for food insecurity for Aboriginal $v$. non-Aboriginal households was $5 \cdot 2(95 \% \mathrm{CI} 4 \cdot 2,6 \cdot 3)$. Of Aboriginal households, $19 \%$ had moderate food insecurity and $14 \%$ had severe food insecurity; whereas of non-Aboriginal households, $6 \%$ had moderate food insecurity and 3\% had severe food insecurity.

Table 1 provides the distribution of categories of sociodemographic variables in Aboriginal and nonAboriginal households, the prevalence of food insecurity for each variable, and univariate and adjusted odds ratios for food insecurity. Aboriginal households had a higher prevalence of risk factors for food insecurity than non-Aboriginal households and experienced a greater prevalence of food insecurity than non-Aboriginal households with similar risk factors. Overall, $17 \cdot 9 \%$ of Aboriginal households received social assistance as compared with $3 \cdot 5 \%$ of non-Aboriginal households. Of Aboriginal households having a main source of income other than wages and salaries, $47 \%$ received social assistance and $51 \%$ were food insecure. By comparison, of non-Aboriginal in this category, $12 \%$ received social assistance and 13\% were food insecure. The percentage of households headed by females was high for both Aboriginal (91\%) and non-Aboriginal (85\%) lone-parent households. Half (51\%) of Aboriginal households with three or more children were food insecure as compared with $13 \%$ of non-Aboriginal households with this many children. After adjusting for sociodemographic factors, Aboriginal but not non-Aboriginal households with three or more children had higher odds for food insecurity than households without children.

Table 2 shows the odds ratios for household food insecurity for each sociodemographic variable adjusted for Aboriginal ethnicity, as well as the final multiple regression model adjusted for Aboriginal ethnicity and all sociodemographic factors. Aboriginal households had higher odds for food insecurity compared with nonAboriginal households (adjusted OR 2·6, $95 \%$ CI 2·1, 3·2). There were no statistically significant first-order interactions between any covariate and ethnic status.

\section{Discussion}

The CCHS 2.2 offered the first opportunity to derive population estimates of the household food insecurity status of the off-reserve Aboriginal population in the context of financial resource constraint ${ }^{(12)}$. Aboriginal households were more likely than non-Aboriginal households participating in the CCHS 2.2 to have overall (33\% v. 9\%), moderate (19\% v. 6\%) and severe (14\%v. $3 \%$ ) food insecurity. Even after controlling for differences in household sociodemographic risk factors, Aboriginal households had $2 \cdot 6$ times greater odds for food insecurity than non-Aboriginal households.

A greater proportion of Aboriginal households was in the lowest income adequacy category and relied on social assistance for income. A previous study reported that $59.7 \%$ of all Canadian households relying on social assistance in the CCHS 2.2 were food insecure, and that $66.7 \%$ of Aboriginal households that received social assistance were food insecure ${ }^{(12)}$. In Canada, social assistance funds fall below Statistics Canada's Low Income Cut-Offs (unofficial poverty lines), and fail to provide sufficient income for an adequate material standard of living and economic security ${ }^{(1,20)}$. Consequently, in households receiving social assistance, often funds meant for food are spent on other essentials such as shelter and utilities ${ }^{(1)}$. Therefore, the likely explanation for the higher prevalence of food insecurity in Aboriginal households is a greater depth of poverty. The Canadian federal government has established targeted, strategic initiatives to address the interrelated causes of poverty and inequality in Aboriginal Canadians; however, only recently has the off-reserve Aboriginal population been considered in initiatives to eradicate poverty ${ }^{(21)}$. The findings from the CCHS 2.2 indicate that to alleviate food insecurity in the off-reserve Aboriginal population, government initiatives must address poverty by increasing income and social assistance funding for families receiving welfare. 


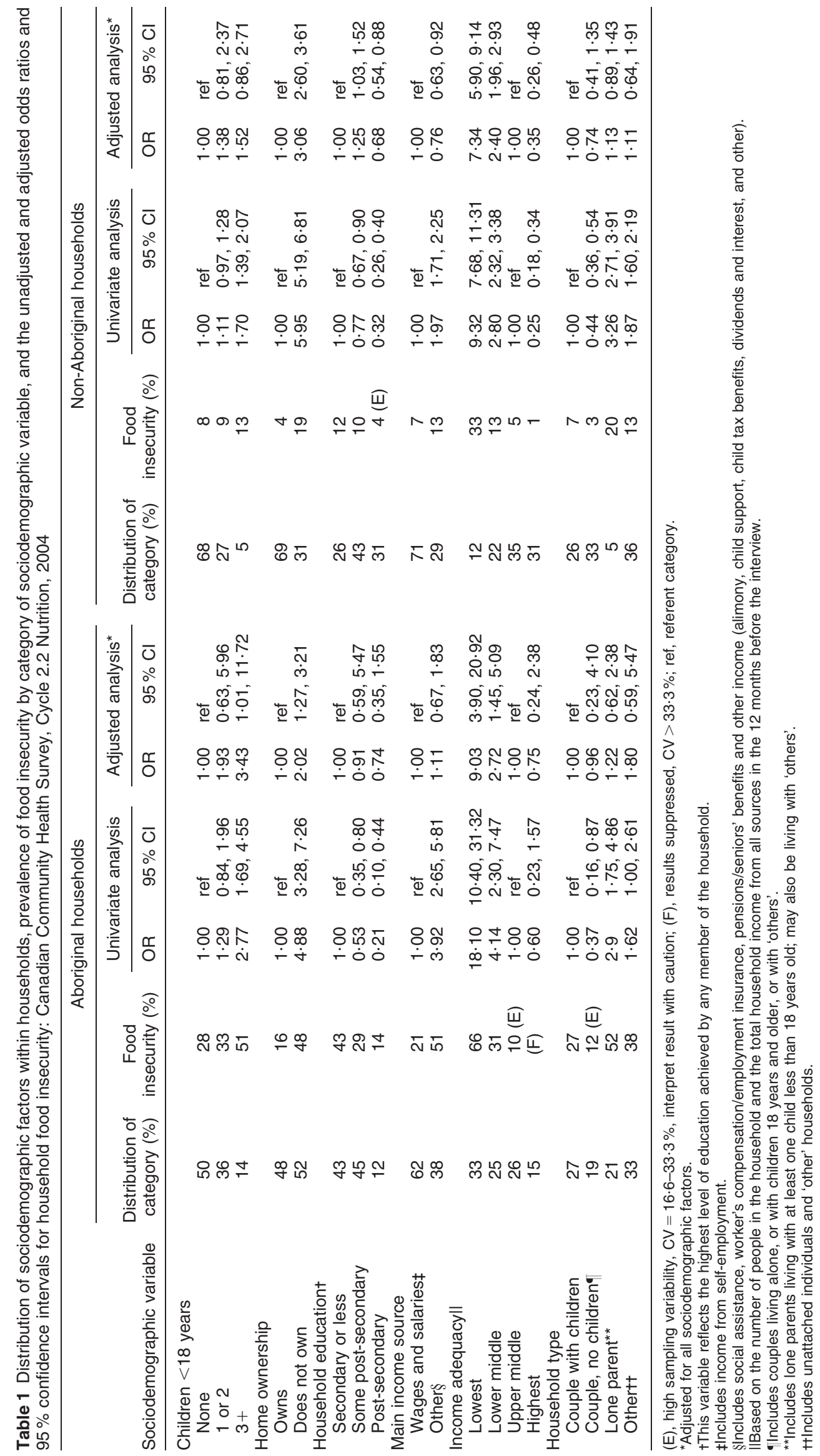


Table 2 Aboriginal status adjusted and multivariable adjusted odds ratios and $95 \%$ confidence intervals for living in a household with food insecurity: Canadian Community Health Survey, Cycle 2.2 Nutrition, 2004

\begin{tabular}{|c|c|c|c|c|}
\hline & \multicolumn{2}{|c|}{ Aboriginal status adjusted } & \multicolumn{2}{|c|}{ Multivariable adjusted $^{*}$} \\
\hline & OR & $95 \% \mathrm{Cl}$ & OR & $95 \% \mathrm{Cl}$ \\
\hline \multicolumn{5}{|l|}{ Aboriginal status } \\
\hline No & $\mathrm{n} / \mathrm{a}$ & & $1 \cdot 00$ & ref \\
\hline Yes & $\mathrm{n} / \mathrm{a}$ & & $2 \cdot 61$ & $2 \cdot 10,3 \cdot 24$ \\
\hline \multicolumn{5}{|l|}{ Number of children } \\
\hline None & 1.00 & ref & 1.00 & ref \\
\hline 1 or 2 & $1 \cdot 12$ & $0 \cdot 98,1 \cdot 28$ & $1 \cdot 43$ & $0 \cdot 85,2 \cdot 39$ \\
\hline $3+$ & $1 \cdot 76$ & $1 \cdot 47,2 \cdot 12$ & $1 \cdot 63$ & $0.94,2 \cdot 83$ \\
\hline \multicolumn{5}{|l|}{ Household type } \\
\hline Couple with children & $1 \cdot 00$ & ref & $1 \cdot 00$ & ref \\
\hline Couple, no children & 0.44 & $0.36,0.54$ & $0 \cdot 76$ & $0.44,1 \cdot 34$ \\
\hline Lone parent & $3 \cdot 24$ & $2 \cdot 72,3 \cdot 86$ & $1 \cdot 14$ & $0.91,1.42$ \\
\hline Other & $1 \cdot 86$ & $1 \cdot 59,2 \cdot 17$ & $1 \cdot 15$ & $0.68,1.92$ \\
\hline \multicolumn{5}{|l|}{ Home ownership } \\
\hline Owns & $1 \cdot 00$ & ref & $1 \cdot 00$ & ref \\
\hline Does not own & $5 \cdot 90$ & $5 \cdot 18,6 \cdot 73$ & $3 \cdot 02$ & $2 \cdot 59,3.53$ \\
\hline \multicolumn{5}{|c|}{ Highest level of education in household } \\
\hline Secondary or less & $1 \cdot 00$ & ref & $1 \cdot 00$ & ref \\
\hline Some post-secondary & $0 \cdot 76$ & $0 \cdot 66,0 \cdot 87$ & $1 \cdot 24$ & $1 \cdot 04,1 \cdot 48$ \\
\hline Post-secondary graduate & 0.32 & $0.26,0.39$ & 0.68 & $0.54,0.87$ \\
\hline \multicolumn{5}{|c|}{ Main source of household income } \\
\hline Wages and salaries & $1 \cdot 00$ & ref & $1 \cdot 00$ & ref \\
\hline Other & $2 \cdot 02$ & $1 \cdot 78,2 \cdot 31$ & $0 \cdot 77$ & $0.64,0.93$ \\
\hline \multicolumn{5}{|l|}{ Household income adequacy } \\
\hline Lowest & $9 \cdot 52$ & $7 \cdot 89,11 \cdot 50$ & $7 \cdot 36$ & $5 \cdot 91,9 \cdot 16$ \\
\hline Lower middle & $2 \cdot 83$ & $2 \cdot 35,3 \cdot 40$ & $2 \cdot 39$ & $1.96,2.91$ \\
\hline Upper middle & 1.00 & ref & $1 \cdot 00$ & ref \\
\hline Highest & 0.25 & $0 \cdot 19,0.34$ & 0.36 & $0.26,0.49$ \\
\hline
\end{tabular}

n/a, not applicable; ref, referent category.

${ }^{*}$ Adjusted for Aboriginal status and for sociodemographic factors.

Aboriginal households with three or more children and lone-parent Aboriginal households participating in the CCHS 2.2 experienced a greater prevalence of food insecurity than non-Aboriginal households under these conditions. The majority of lone-parent households were headed by women. In these types of households mothers tend to sacrifice their own diet so that children will not be hungry ${ }^{(22)}$. It is critical that lone-parent Aboriginal mothers and Aboriginal households with multiple children be provided with sufficient financial resources to ensure that parents and their children do not go hungry or experience anxiety about not having sufficient food to eat. The National Child Benefit (NCB) is a federal government initiative to reduce child poverty; however, some provinces reduce the amount of social assistance a family receives by the amount of the $\mathrm{NCB}^{(1)}$. Policy initiatives such as increasing the amount of the NCB for each additional child, and eliminating the claw back of the NCB from families receiving social assistance, have the potential to improve the economic conditions of many Aboriginal families at risk for food insecurity ${ }^{(1)}$.

Unexplored or unmeasured factors may be responsible for the higher prevalence of food insecurity in Aboriginal households. If the material, behavioural and psychological circumstances associated with the vulnerability to food insecurity vary between Aboriginal and non-Aboriginal households, then the lived experience of food insecurity would be distinct between the two groups. There is little knowledge about how or if Aboriginal household dynamics such as crowding or living in multiple-family households influence food insecurity. The HFSSM does not capture the strategies used to cope with food insecurity ${ }^{(14)}$. Coping strategies for off-reserve Aboriginal households may be unique, such as accessing traditional foods from friends and family with access to land for hunting. To effectively promote and support healthy eating among Aboriginal peoples living off-reserve, there is the need for a comprehensive understanding of the many factors related to food security that influence food procurement, purchasing and eating behaviour, such as cycles of food expenditure in relation to the arrival of pay cheques or government welfare cheques, as well as strategies to meet food needs, including the use of charities such as food banks from community foodassistance providers ${ }^{(23)}$. Qualitative studies to better understand the circumstances of Aboriginal people's lives under conditions of household food insecurity, as well as coping strategies used by Aboriginal households to address food insecurity, from anxiety to hunger, are required ${ }^{(24)}$. The findings would allow food security programmes to be tailored to the unique needs of the Aboriginal population.

There are several limitations to the study based on sample size and survey design. Small numbers precluded severe food insecurity being considered an outcome variable even though members of households in this 
grouping merited their own analysis given that they may have experienced severe food deprivation and hunger ${ }^{(12)}$. As a result of the relatively small number of Aboriginal respondents, sociodemographic data were aggregated, even though aggregate data hide disparities and variation in the material and other circumstances of people's lives. The Aboriginal population of Canada is very heterogeneous, culturally, geographically and linguistically; however, separate analysis was not possible for the three cultural groups of Aboriginal respondents. If future surveys were to include a larger sample of the Aboriginal population, disaggregated information for each of Métis, First Nations and Inuit, as well as for individuals with sole and mixed Aboriginal identity, would provide a diversity of data to inform public policy about food security. It is probable that the extent of household food insecurity was underestimated by the survey because some households defined as food secure using the HFSSM may have had marginal food security status $^{(12)}$. In addition, excluded from the survey sampling frame were populations living in the territories which often have limited economic opportunities and high food costs, and thus a high prevalence of food insecurity ${ }^{(5,7)}$. Given the demand for a wide range of information on a small population, managing respondent burden in the territories is a significant challenge. Statistics Canada is working with the territorial governments to prioritize data requirements and to make data collection as cost-effective as possible. Health Canada supports this process (personal communication by email, September 2008).

\section{Conclusions}

Off-reserve Aboriginal households merit special attention for income security and poverty alleviation programmes. Monitoring changes in income-related household food insecurity in the off-reserve Aboriginal population in future Canadian Community Health Surveys using the HFSSM will allow the effectiveness of initiatives to reduce poverty to be evaluated. A larger sample would permit better discernment of factors that might account for the higher rate of food insecurity in Aboriginal households. Conceptualization of food security for a diversity of Aboriginal peoples requires qualitative research.

\section{Acknowledgements}

Sources of funding: Funding was from the Canadian Institutes of Health Research - Institute of Nutrition, Metabolism and Diabetes, Statistics Canada and Health Canada. N.D.W., K.R. and P.V. acknowledge salary support from the Alberta Heritage Foundation for Medical Research and the Canadian Institutes of Health Research and the Canada Research Chairs Program. Conflict of interest declaration: None to declare. Authorship responsibilities: N.D.W. did the literature review, worked on the analytical design and data interpretation, and wrote the manuscript drafts; S.K. did the statistical analyses and data management, designed the tables and provided input on the manuscript drafts; P.V. helped with study design, guided the analytical strategies and provided input on the drafts; K.R. read manuscript drafts and assisted with the development of the study design. Disclaimer: The opinions expressed in this paper are those of the authors and do not represent the views of Statistics Canada.

\section{References}

1. Power E (2005) Individual and household food insecurity in Canada: position of Dietitians of Canada. http://www. dietitians.ca/news/downloads/Food_Insecurity_position.pdf (accessed September 2008).

2. Life Sciences Research Office (1990) Core indicators of nutritional status for difficult-to-sample populations. $J$ Nutr 120, Suppl., 1559-1600.

3. McIntyre L, Connor SK \& Warren J (2000) Child hunger in Canada: results of the 1994 National Longitudinal Survey of Children and Youth. CMAJ 163, 961-965.

4. Che J \& Chen J (2001) Food insecurity in Canadian households. Health Rep 12, 11-22.

5. Lawn J \& Harvey D (2004) Nutrition and Food Security in Kangiqsujuaq, Nunavik: Baseline Survey for the Food Mail Pilot Project. Ottawa: Indian and Northern Affairs Canada.

6. Willows ND, Iserhoff R, Napash L, Leclerc L \& Verrall T (2005) Anxiety about food supply in Cree women with infants in Quebec. Int J Circumpolar Health 64, 59-68.

7. Chan HM, Fediuk K, Hamilton S, Rostas L, Caughey A, Kuhnlein H, Egeland G \& Loring E (2006) Food security in Nunavut, Canada: barriers and recommendations. Int $J$ Circumpolar Health 65, 416-431.

8. Drost H \& Richards J (2003) Income On-and Off-reserve: How Aboriginals are Faring. C.D. Howe Institute Commentary no. 175. Ottawa: Renouf Publishing Co. Ltd; available at http://www.cdhowe.org/pdf/commentary_175. pdf

9. Cloutier E, Costa R, Germain M-F et al. (2008) Aboriginal Peoples in Canada in 2006: Inuit, Métis and First Nations, 2006 Census: Findings. Ottawa: Statistics Canada; available at http://www12.statcan.ca/english/census06/analysis/ aboriginal/pdf/97-558-XIE2006001.pdf

10. Young TK (2003) Review of research on aboriginal populations in Canada: relevance to their health needs. BMJ 327, 419-422.

11. Health Canada (2006) Canadian Community Health Survey, Cycle 2.2, Nutrition (2004). A Guide to Accessing and Interpreting the Data. Ottawa: Minister of Health, Office of Nutrition Policy and Promotion, Health Products and Food Branch, Health Canada.

12. Health Canada (2007) Canadian Community Health Survey, Cycle 2.2, Nutrition (2004). Income-Related Household Food Security in Canada. http://www.hc-sc.gc.ca/fn-an/ alt_formats/hpfb-dgpsa/pdf/surveill/income_food_sec-sec_ alim_e.pdf (accessed June 2008).

13. Health Canada (2007) Canada Nutrition and Health Atlas (CNHA). http://www.hc-sc.gc.ca/fn-an/surveill/atlas/ province/index-eng.php (accessed September 2008).

14. Tarasuk V (2001) Discussion Paper on Housebold and Individual Food Insecurity. A report prepared for the Office of Nutrition Policy and Promotion, Health Canada. Ottawa: Health Canada. 
15. Statistics Canada (2008) Canada's National Statistical Agency Research Data Centre. http://www.statcan.ca/ english/rdc/index.htm (accessed September 2008).

16. Statistics Canada (2005) Canadian Community Health Survey (CCHS) Cycle 2.2 (Nutrition) 2004 Public Use Microdata File (PUMF) Derived and Grouped Variable Specifications. http://www.statcan.ca/english/sdds/document/ 5049_D8_T9_V1_E.pdf (accessed September 2008).

17. Hosmer DW \& Lemeshow S (2000) Applied Logistic Regression. New York: Wiley.

18. Rust KF \& Rao JN (1996) Variance estimation for complex surveys using replication techniques. Stat Methods Med Res 5, 283-310.

19. Piérard E, Buckley N \& Chowhan J (2004) Bootstrapping made easy: a Stata ADO file. The Research Data Centres Information and Technical Bulletin 1, 20-36.
20. Mulvale JP (2008) Basic income and the Canadian welfare state: exploring the realms of possibility. Basic Income Studies 3, 1-2.

21. Indian and Northern Affairs Canada (2005) Millennium Development Goals and Indigenous Peoples Goal 1: 'Eradicate Extreme Poverty And Hunger' (Combating Poverty: Good Practices and Barriers to Implementation). http://www.ainc-inac.gc.ca/nr/spch/unp/05/fis/mdg_e.html (accessed June 2008).

22. McIntyre L, Glanville NT, Raine KD, Dayle JB, Anderson B \& Battaglia N (2003) Do low-income lone mothers compromise their nutrition to feed their children? CMAJ 168, 686-691.

23. Willows ND (2005) Determinants of healthy eating in Aboriginal peoples in Canada: the current state of knowledge and research gaps. Can J Public Health 96, S32-S36.

24. Power EM (2008) Conceptualizing food security for Aboriginal People in Canada. Can J Public Health 97, 95-97. 